Rafat Michatowski

\title{
Charakter prawny \\ oraz konsekwencje naruszenia pierwszeństwa w nabyciu nieruchomości Zasobu Własności Rolnej Skarbu Państwa
}

W niniejszym artykule zajmuję się niektórymi zagadnieniami związanymi z pierwszeństwem w nabyciu nieruchomości z Zasobu Własności Rolnej Skarbu Państwa, o którym mowa w art. 29 ust. 1-1g ustawy z dnia 19 października $1991 \mathrm{r}$. o gospodarowaniu nieruchomościami rolnymi Skarbu Państwa ${ }^{1}$. Bezpośrednią inspiracją dla jego napisania są dwie wypowiedzi Sądu Najwyższego: uchwała z dnia 21 grudnia 2006 r. ${ }^{2}$ oraz uchwała z dnia 7 października 2008 r. ${ }^{3}$ Wypada zauważyć, że Sąd Najwyższy wcześniej wielokrotnie wypowiadał się w kwestii pierwszeństwa uregulowanego przede wszystkim przepisami odnoszącymi się do gospodarowania nieruchomościami zurbanizowanymi na podstawie ustawy z dnia 29 kwietnia 1985 r. o gospodarce gruntami i wywłaszczaniu nieruchomości ${ }^{4}$, a także w ustawie z dnia 21 sierpnia 1997 r. o gospodarce nieruchomościami ${ }^{5}$. Uboższy jest jego dorobek w postaci publikowanych rozstrzygnięć opartych na przepisach u.g.n.r. Stąd też dwie przywołane wyżej uchwały z pewnością będą miały duży wpływ na kształtowanie się poglądów doktryny oraz na stanowisko zajmowane przez sądy rozstrzygające spory powstałe na tle funkcjonowania tej instytucji. Osiągnięcia orzecznictwa dotyczące pierwszeństwa nabycia nieruchomości zurbanizowanych, jak i poglądy doktryny w tym zakresie są jednak cenne również przy analizie odpowiednich uregulowań u.g.n.r. z racji ich podobieństwa. Zostaną więc wykorzystane w dalszym toku rozważań.

Pierwszeństwo w nabyciu nieruchomości Skarbu Państwa i jednostek samorządu terytorialnego należy do konstrukcji prawnych cieszących się relatywnie dużym zainteresowaniem przedstawicieli doktryny, owocującym zróżnicowaniem wyrażonych poglądów w przedmiocie skutków jego naruszenia, a także jego charakte-

\footnotetext{
Dz.U. z 2007 r. Nr 231, poz. 1700, powoływana dalej jako u.g.n.r.

III CZP 121/06, OSNC 2007, nr 10, poz. 149.

Biuletyn SN 2008, nr 10, s. 7.

Dz.U. z 1991 r. Nr 30, poz. 127 z późn. zm. (dalej powoływana jako u.g.g.); ustawa została uchylona na mocy art. 241 pkt 1 ustawy powołanej w przyp. 5.

$5 \quad$ Dz.U. z 2004 r. Nr 261, poz. 2603 z późn. zm., powoływana dalej jako u.g.n.
} 
ru prawnego. Orzecznictwo Sądu Najwyższego zachowuje jednolitość w określeniu jego istoty. Nie można powiedzieć tego samego w odniesieniu do stanowiska Sądu Najwyższego w kwestii oznaczenia sankcji uchybienia pierwszeństwu - jednak w orzecznictwie ostatnich lat ta niejednolitość została przełamana i można chyba mówić o ustalonej linii orzecznictwa w tym zakresie. Owa niejednomyślność w poglądach jest spowodowana z jednej strony niedoskonałością przepisów prawa nieokreślających w sposób dostatecznie precyzyjny dla interpretatora aktu prawnego wszystkich aspektów pierwszeństwa, z drugiej zaś brakiem spójnej wizji prawodawcy w jego uregulowaniu, prowokującej do zadania pytania, czy mamy do czynienia z jednym pierwszeństwem w nabyciu nieruchomości czy też instytucją niejednolitą i w związku z tym posiadającą swoiste na tle danego aktu prawnego, przynajmniej w pewnej mierze, odrębne regulacje. Zajęte w tej kwestii stanowisko pociąga za sobą odmienne rozstrzygnięcie co do ustalenia konsekwencji naruszenia pierwszeństwa.

Próba określenia istoty pierwszeństwa w nabyciu nieruchomości została podjęta w uchwale Sądu Najwyższego z dnia 23 lipca 1992 r., ${ }^{6}$ gdzie zawarto stwierdzenie, że: ,pierwszeństwo polega przede wszystkim na eliminacji innych podmiotów ubiegających się o tę samą rzecz. Jego konstrukcja jurydyczna nie jest oparta na uprawnieniu, lecz na tkwiącym immanentnie w pierwszeństwie zakazie zadysponowania rzeczą w sposób je naruszający. Realizacja pierwszeństwa jest zatem możliwa dopiero wówczas, gdy adresat zakazu stworzy swym zachowaniem sytuację, w której zakaz staje się aktualny. Te sytuacje stanowią jednocześnie granice, w jakich uprzywilejowanie pierwszeństwem, oznaczające intencjonalne pogorszenie sytuacji prawnej jednej ze stron, znajduje uzasadnienie w przyzwoleniu ustawodawcy." Sąd Najwyższy, w kolejnych, następujących po tej uchwale orzeczeniach odnoszących się do pierwszeństwa, aprobował zaprezentowany w niej sposób jego pojmowania ${ }^{7}$. Często również przedstawiciele doktryny, analizując konstrukcję pierwszeństwa, bezpośrednio powoływali się na uchwałę z dnia 23 lipca 1992 r., akceptując wnioski Sądu Najwyższego w tej kwestii ${ }^{8}$. Niektórzy z nich ograniczali się jedynie do cytowania bez komentarza przytoczone wyżej sformułowania, jednakże należy odnotować, że niektórzy autorzy starali się przeprowadzić analizę istoty pierwszeństwa, osadzając jej szkielet zarysowany przez Sąd Najwyższy w ramach elementarnych pojęć teorii prawa. I tak w szczególności K. Świderski uznał, że pierwszeństwo na-

$6 \quad$ III CZP 62/92, OSNCP 1992, nr 12, poz. 214

7 Zob. wyrok SN z dnia 20 stycznia 1997 r., III CKN 368/97, OSNC 1998, nr 9, poz. 143; wyrok SN z dnia 9 lipca 1999 r., III CKN 98/99, OSP 2000, nr 1, poz. 5; wyrok SN z dnia 26 lipca 2001, II CKN 1181/00, Lex nr 51968; uchwałę SN z dnia 21 grudnia 2006 r., III CZP 121/06 przywołaną w przyp. 2.

8

Zob. przykładowo, S. Rudnicki, Prawo odkupu, pierwokupu i pierwszeństwo nabycia, (w:) Prawo obrotu nieruchomościami, pod red. S. Rudnickiego, Warszawa 2001, s. 539; E. Klat-Górska, Pierwszeństwo w nabyciu nieruchomości według art. 29 ustawy o gospodarowaniu nieruchomościami rolnymi Skarbu Państwa, (w:) Prawo rolne. Problemy teorii i praktyki, pod red. R. Budzinowskiego i A. Zielińskiego, Kluczbork 2001, s. 206; M. Horoszko, D. Pęchorzewski (red.), Gospodarka nieruchomościami. Komentarz, Warszawa 2009, s. 138. 
leży rozumieć jako skierowany do zobowiązanego ustawowy nakaz stworzenia osobie uprawnionej możności kupna przed innymi osobami nieruchomości, co do której wyraziła ona zamiar zbycia ${ }^{9}$. Stąd ma - zdaniem autora - wynikać, że mamy tu do czynienia z podstawową modalnością prawną, przez co wykluczony jest w szczególności wniosek, że pierwszeństwo jako takie jest źródłem roszczenia ${ }^{10}$. Należy przy tym wyjaśnić, że podstawową modalnością prawną jest taka sytuacja prawna, w której nałożony na adresata normy prawnej obowiązek nie polega w szczególności na świadczeniu czegoś komuś - można tu podać często podawany przykład powszechnego obowiązku szczepień. W tym przypadku nie da się wskazać podmiotu, o którym można by powiedzieć, że jest z tego tytułu uprawniony. Z pochodną modalnością normatywną mamy do czynienia między innymi wówczas, gdy nałożony na adresata normy obowiązek zachowania w jakiś sposób odnosi się do sfery interesów innej osoby, jak jest zwłaszcza w przypadku zobowiązaniowych stosunków prawnych $^{11}$.

Szczegółową analizę konstrukcji pierwszeństwa w nabyciu nieruchomości przedstawiła B. Burian. Według niej, pierwszeństwo polega na tym, że w sytuacji podjęcia przez właściciela nieruchomości decyzji o rozporządzeniu nią, wskazane kategorie podmiotów mogą ją nabyć z pominięciem trybu przetargu, czyli przy wyeliminowaniu innych chętnych ${ }^{12}$. Pierwszeństwo uprzywilejowuje określone podmioty w ten sposób, że na wypadek rozporządzenia przez właściciela nieruchomością przyznaje im prawo do nabycia własności nieruchomości z pominięciem innych ewentualnie zainteresowanych, a nie upoważnionych pierwszeństwem ${ }^{13}$. Nie wprowadzono przy tym możności domagania się przez upoważnionego pierwszeństwem zawarcia umowy przenoszącej własność, mimo że norma prawna nakłada na właściciela powinność jego uwzględnienia, a więc obowiązek zawarcia umowy ${ }^{14}$. Stąd „,nawet zgłoszenie przez upoważnionych pierwszeństwa do nabycia nieruchomości nie aktualizuje po stronie właściciela nakazu zbycia nieruchomości właśnie tym osobom", przez co w tej sytuacji, pomimo że norma prawna nakłada na dany podmiot obowiązek określonego zachowania, to nikomu innemu nie przyznano uprawnienia będącego jego korelatem ${ }^{15}$. Autorka dochodzi do konkluzji, że ,bez roszczenia nie ma de facto nakazu (rozumianego jako taki zakaz dokonania czynności prawnej,

9 K. Świderski, Charakter prawny pierwszeństwa w nabyciu nieruchomości, Rejent 2000, nr 11, s. 111.

10 Tamże

11 S. Wronkowska, (w:) S. Wronkowska, Z. Ziembiński, Zarys teorii prawa, Poznań 2001, s. 100 i nast.; Z. Ziembiński, Problemy podstawowe prawoznawstwa, Warszawa 1980, s. 172 i nast.

B. Burian, Pierwszeństwo nabycia nieruchomości, Kraków 2004, s. 207. Autorka zaznacza tam, że powyższe sformułowanie dotyczy pierwszeństwa uregulowanego przepisami u.g.n. Jednakże ma ono doniosłość także dla pierwszeństwa uregulowanego przez u.g.n.r. - autorka podkreśla podobieństwo konstrukcji prawnej obu pierwszeństw; zob. tamże, s. 190-191. Tamże, s. 191, 195, 204, 208.

14 Tamże, s. 191. wstępnej o skutku słabszym (art. $390 \S 1$ kc.) - zob. przypis 386, s. 191. 
którego naruszenie powodowałoby nieważność czynności realizowania pierwszeństwa, nie ma zatem zakazu dokonania czynności prawnej z jego naruszeniem"16.

Nie można jednak powiedzieć, że brak jest w doktrynie prób wprowadzenia pojęcia uprawnienia do opisu konstrukcji pierwszeństwa. M. Safjan zauważył, że można dopuścić posługiwanie się przy jego charakterystyce pojęciem uprawnienia, gdyż korelatem pierwszeństwa jest określony obowiązek, uchybienie któremu pociąga za sobą wskazaną przez prawodawcę sankcję cywilnoprawną ${ }^{17}$. Dalej, jak się wydaje, idzie J. Szachułowicz, stwierdzając w toku rozważań poświęconych pierwszeństwu w u.g.n., że uprawnienie to zostało ukształtowane jako roszczenie ${ }^{18}$. Także M. Wolanin uznaje, że prawo pierwszeństwa w u.g.n. jest posiadającym źródło ustawowe roszczeniem, którego można dochodzić przed sądem cywilnym ${ }^{19}$. Należy też odnotować, że na gruncie u.g.n.r. pojawiły się opinie (formułowane przez A. Stelmachowskiego, S. Prutisa oraz M. Czapską-Górnikiewicz), że osoby uprzywilejowane pierwszeństwem mają z tego tytułu roszczenie o zawarcie umowy ${ }^{20}$. Pogląd o ukształtowaniu pierwszeństwa jako roszczenia musi zostać uznany za niezwykle kontrowersyjny, gdyż w wielu, w tym przywołanych przeze mnie wcześniej wypowiedziach piśmiennictwa, jak i w orzecznictwa, jest to kategorycznie wykluczane. Dotyczy to zarówno stanu prawnego wynikającego z przepisów u.g.g., jak i wynikającego z u.g.n. ${ }^{21}$. Ukształtowanie pierwszeństwa pod postacią roszczenia wysunięto natomiast jako postulat de lege ferend $a^{22}$.

Wydaje się jednak, że dominujące stanowisko, podążające przy wyjaśnieniu istoty analizowanej instytucji za wnioskami wynikającymi z uchwały Sądu Najwyższego z dnia 23 lipca 1992 r., wymaga pewnego uściślenia. Trafnie zauważył R. Trzaskowski, że pierwszeństwo oznacza nakaz jego respektowania i zgodnie z wnioskowaniem na podstawie reguły instrumentalnego zakazu - zakaz działań, które byłyby wystarczające dla uchybienia powyższemu nakazowi ${ }^{23}$. Należy więc, poprzez

Tamże, s. 196. Na niekonsekwencję w argumentacji autorki trafnie zwraca uwagę R. Trzaskowski, Skutki naruszenia pierwszeństwa w braku wyraźnej regulacji ustawowej, Palestra 2007, nr 7-8, s. 262.

17 M. Safjan, (w:) Kodeks cywilny. Komentarz, t. II, pod red. K. Pietrzykowskiego, Warszawa 2005, s. 299. Autor wyraził opinię na gruncie przepisów u.g.n.

18 J. Szachułowicz, Gospodarka nieruchomościami, Warszawa 2005, s. 63 („Uprawnienie to zostało ukształtowane jako roszczenie.”). W innej, wcześniejszej wypowiedzi autor wyraził stanowisko zgoła odmienne; zob. tegoż, Własność publiczna, Warszawa 2000, s. 192 („Uprawnienie to nie stanowi roszczenia o zawarcie umowy.”). M. Wolanin, Zbycie nieruchomości przez jednostki samorządu terytorialnego, Nieruchomości 2004, nr 11, s. 8. A. Stelmachowski, (w:) System prawa prywatnego. Prawo rzeczowe, t. III, Warszawa 2003, s. 370; S. Prutis, Gospodarowanie nieruchomościami rolnymi Skarbu Państwa. Komentarz i orzecznictwo SN i NSA, Białystok 1997, s. 102, tenże, (w:) Prawo rolne, pod red. A. Stelmachowskiego, Warszawa 2008, s. 230; M. Czapska-Górnikiewicz, Agencja Własności Rolnej Skarbu Państwa - zagadnienia wybrane, Rejent 1994, nr 7-8, s. 84.

J. Frelich, Zasada pierwszeństwa wyrażona w art. 34 ust. 1 ustawy o gospodarce nieruchomościami w świetle uchwały nr W 19/95 Trybunału Konstytucyjnego, Rejent 1998, nr 10, s. 90. Brak roszczenia w konstrukcji pierwszeństwa wyraźnie akcentuje E. Gniewek, Obrót nieruchomościami skarbowymi i samorządowymi, Kraków 1999, s. 176. Na tle u.g.n.r. zob. zwłaszcza, E. Kremer, Instytucja pierwszeństwa nabycia nieruchomości, Studia luridica Agraria 2007, t. 6, s. 141-142.

22 M. Nazar, Sprzedaż lokali z gminnego zasobu nieruchomości, Rejent 1998, nr 12, s. 146-147.

23 R. Trzaskowski, Granice swobody kształtowania treści i celu umów obligacyjnych. Art. 3531 kc., Kraków 2005 , s. 258. Por. R. Padrak, Pierwszeństwo nabycia nieruchomości w ustawie o gospodarce nieruchomościami, Fi- 
zachowanie określonej procedury, stworzyć podmiotowi, któremu pierwszeństwo przysługuje, sposobność do skorzystania z niego. Temu służy obowiązek zawiadomienia o zamiarze zbycia nieruchomości oraz nakaz oczekiwania na odpowiedź ${ }^{4}$. Oczywiste jest, że nie można wówczas dopuścić, aby umowa sprzedaży nieruchomości została zawarta z innym podmiotem. Jest to dozwolone dopiero, gdy złożone zostanie oświadczenie o braku zamiaru skorzystania z pierwszeństwa (ewentualnie w razie niezłożenia żadnego oświadczenia). Nie można uznać, że pierwszeństwo jest redukowalne do samego tylko zakazu zbycia nieruchomości innej osobie niż wskazanej przepisami wyznaczającymi katalog podmiotów mogących skorzystać z pierwszeństwa. Z samego zakazu zbycia nieruchomości osobom innym niż uwzględnione w katalogu uprzywilejowanych (jeśli rozumieć tu uprzywilejowanie jako wyłączenie ze zbioru podmiotów, na rzecz których zbycie nie może nastąpić) nie da się wyprowadzić nakazu podejmowania jakichkolwiek czynności wobec niej, stwarzających możliwość nabycia gruntu. Odwrotnie - to właśnie zakaz zbywania nieruchomości wynika z nałożenia tego nakazu. W stanowisku wyrażonym w uchwale z dnia 23 lipca 1992 r. akcent jest położony na zakaz dysponowania nieruchomością, jednak dookreślony sformułowaniem: „w sposób je (to jest - pierwszeństwo, podkr. R.M.) naruszający”. Z niego właśnie należy wyciągnąć wniosek, że z zakazem tym związany jest nakaz określonego zachowania względem tego, komu pierwszeństwo przysługuje. Jednak, moim zdaniem, Sąd Najwyższy dla bardziej przejrzystego opisania sytuacji wyznaczonej przepisami wyznaczającymi pierwszeństwo na pierwszy plan powinien wyeksponować element nakazu. Ponieważ nakaz ten dotyczy postępowania wobec oznaczonej osoby i jest - standardowo rzecz biorąc - dla niej korzystny, to powstaje pytanie, czy nie da się tu dostrzec pochodnej modalności normatywnej (uprawnienia), co wykluczył Sąd Najwyższy, a w doktrynie przykładowo K. Świderski. Stąd, mając na uwadze głos M. Safjana, do rozważenia pozostaje kwestia, czy nie byłoby dopuszczalne posługiwanie się pojęciem uprawnienia przy opisie sytuacji osoby, której przyznano pierwszeństwo. Nie byłoby to jednak, co trzeba wyraźnie podkreślić, od razu równoznaczne z przyznaniem jej roszczenia o zawarcie umowy sprzedaży, które może być dochodzone w drodze powództwa $\mathrm{z}$ art. $64 \mathrm{kc}$. i art. $1047 \S 1 \mathrm{kpc}$. Uzewnętrznienie woli zadysponowania nieruchomością poprzez udostępnienie wykazu nieruchomości przeznaczonych do zbycia (nawet z oznaczeniem ceny nieruchomości) czy też indywidualne powiadomienie uprawnionych nie wystarczy dla jego powstania. Na gruncie u.g.n. zdecydowanie dominuje stanowisko, że złożenie wniosku o nabycie nieruchomości, nawet w połączeniu ze zgodą na cenę określoną w zawiadomieniu bądź wykazie (zob. art. 34 ust. 4 i 5 u.g.n.), nie pociąga za sobą powstania roszczenia o zawarcie umo-

nanse Komunalne 2006, nr 4, s. 60, który pisze tam, że „pierwszeństwo można także rozumieć jako ustawowy nakaz skierowany do zobowiazanego, aby ten w sytuacji, kiedy ogłosi swój zamiar zbycia nieruchomości, stworzył dla podmiotu uprawnionego możliwość nabycia tej nieruchomości przed innymi osobami”. 
wy sprzedaży. Wniosek ów uzasadniany jest argumentem, że zgodnie z art. 28 ust. 2 u.g.n. warunki zbycia nieruchomości w drodze bezprzetargowej (a więc i zbywanych osobom, którym przysługuje pierwszeństwo - art. 37 ust. 1 pkt 1 u.g.n.) ustala się w rokowaniach przeprowadzanych z nabywcą. Podstawą zawarcia umowy jest zaś protokół z przeprowadzonych rokowań (art. 28 ust. 3 u.g.n.) ${ }^{25}$. Jak stąd wynika, źródłem roszczenia o zawarcie umowy sprzedaży nieruchomości byłyby wobec tego pomyślnie zakończone rokowania, poprzez które realizuje się ów przywilej. Nie budzi zaś wątpliwości, że w wyniku osiągnięcia porozumienia przez uczestników rokowań dotyczących zawarcia umowy sprzedaży nieruchomości skarbowej czy też samorządowej jest powstanie roszczenia, które może być dochodzone w drodze powództwa z art. 64 kc. i z art. 1047 § 1 kpc. ${ }^{26}$ Jednak na tle wniosków wypływających z powyższych spostrzeżeń za budzącą sprzeciw należy uznać opinię, że zawiadomienie uprawnionego o przysługującym mu pierwszeństwie należy uznać za sui generis ofertę, której przyjęcie otwierałoby etap rokowań ${ }^{27}$. W związku z tym, mając na uwadze, że zasadniczo na gruncie prawa cywilnego w ofercie trzeba widzieć oświadczenie woli, należy rozważyć, czy również i w takiej ofercie sui generis da się dostrzec tę cechę. Pojawia się wtedy pytanie, na wywołanie jakich skutków prawnych jest ona skierowana? Chyba jedynym skutkiem przyjęcia takiej oferty byłoby prowadzenie rokowań. Osiągnięciu tego rezultatu służy natomiast zaproszenie do zawarcia umowy, nieposiadające waloru oświadczenia woli. Przeciwko temu zarzutowi można by podnieść kontrargument, że niekiedy zachowaniom określanym jako złożenie oferty nie nadaje kwalifikacji wynikającej z art. $66 \S 1$ kc. ${ }^{28}$ Jeśli jednak chce się ograniczyć skutki pozytywnej odpowiedzi uprzywilejowanego pierwszeństwem na zawiadomienie o możliwości nabycia nieruchomości jedynie do prowadzenia rokowań, nie ma potrzeby wprowadzania w tym celu niejasnych konstrukcji prawnych, których skutki pokrywałyby się ze znanymi już rozwiązaniami. Na koniec tej części rozważań chcę jeszcze zaznaczyć, że niemożność negocjowania ceny określonej w wykazie bądź zawiadomieniu w części postępowania następującej po jej akceptacji przez uprzywilejowanego nie świadczy o tym, że czynności prowadzące do tego skutku powinny być traktowane jako oferta sui generis oraz jej przyjęcie (czy tė̇ sui generis?). Po prostu wystarczy przyjąć, że skutkami powyższych aktów, nieodbiegających charakterem od innych czynności dokonywanych w roko-

Por. K. Świderski, Charakter prawny pierwszeństwa..., s. 102-103; R. Padrak, Pierwszeństwo..., s. 60. Por. też uzasadnienie wyroku Sądu Najwyższego z dnia 12 marca 2003 r., III CKN 857/00, Lex nr 78855, gdzie zawarto stwierdzenie, że „Roszczenie o zawarcie umowy sprzedaży nieruchomości przysługiwałoby zatem uprawnionemu z tytułu pierwszeństwa dopiero w sytuacji, gdyby strony w wyniku przeprowadzonych rokowań uzgodniły wszystkie istotne postanowienia umowy".

26 E. Gniewek, Obrót nieruchomościami..., s. 218-220.

27 R. Padrak, Pierwszeństwo..., s. 60; tenże, Sprzedaż nieruchomości na podstawie ustawy gospodarce nieruchomościami, Warszawa 2005, s. 33, powołując się na wyrok Sądu Najwyższego z dnia 10 stycznia 2001 r., V CKN 1604/00, Lex nr 77072 wydanego na tle przepisów u.g.g. Por. M. Boratyńska, Przetarg w prawie polskim. Zagadnienia cywilistyczne, Warszawa 2001, s. 125. 
waniach, ${ }^{29}$ jest po pierwsze uzgodnienie ceny, z którym to uzgodnieniem powiązany jest ustawowy zakaz jej ponownego negocjowania, po drugie, inicjacja rokowań co do innych postanowień umownych.

Wracając do postawionego pytania o możliwość wprowadzenia pojęcia uprawnienia (w każdym razie tak, jak rozumie się je w prawie cywilnym) do opisu sytuacji uprzywilejowanego pierwszeństwem, mając przy tym na uwadze dotychczasowe wywody, wydaje się to w ramach regulacji u.g.n. dość problematyczne. Przyjmując, że czynności prowadzące do realizacji pierwszeństwa kwalifikowane są jako rokowania, to nie ma tu, biorąc pod uwagę poglądy doktryny, miejsca na konstruowanie cywilnoprawnego stosunku prawnego, którego elementem byłoby takie uprawnienie. Wątpliwe jest, w moim odczuciu, ujmowanie go jako korelatu obowiązku „zapewnienia możliwości skorzystania z pierwszeństwa” z uwagi na jego niedostateczną konkretyzację (wykluczającą zatem postrzeganie go jako świadczenie w rozumieniu art. $353 \mathrm{kc}$.). Wykluczone jest również porównywanie powyższego obowiązku z obowiązkiem spoczywającym na stronie umowy przedwstępnej o skutku słabszym. Tam mamy do czynienia ze skonkretyzowanym uprawnieniem, z którym nie połączono jednak kompetencji do zwrócenia się do sądu o wydanie orzeczenia stwierdzającego obowiązek złożenia oświadczenia woli, uchybienie któremu oceniać należy jednak poprzez art. $471 \mathrm{kc} .^{30}$

Nawet jednak akceptacja stanowiska, zgodnie z którym korzystanie z pierwszeństwa przez wyrażenie zgody na cenę ustaloną w sposób określony w ustawie, jak stanowi art. 34 ust. 5 u.g.n., nie powoduje powstania roszczenia o zawarcie umowy sprzedaży nieruchomości, nie musi mieć, moim zdaniem, automatycznego przełożenia na regulację dotyczącą sprzedaży nieruchomości Zasobu Własności Rolnej Skarbu Państwa. Zgodnie z przepisami u.g.n.r., o przeznaczeniu do sprzedaży nieruchomości, do której nabycia przysługuje pierwszeństwo osobie wymienionej w ust. 1, Agencja zawiadamia na piśmie tę osobę, podając cenę nieruchomości oraz termin złożenia wniosku o nabycie na warunkach podanych w zawiadomieniu, z tym że termin nie może być krótszy niż 21 dni od dnia otrzymania zawiadomienia. Uprawnionego zawiadamia się o przysługującym mu pierwszeństwie na piśmie (art. 29 ust. 1c u.g.n.r.), a jeśli jego adres nie jest znany - funkcję zawiadomienia pełni wykaz nieruchomości sporządzony i ogłoszony stosownie do art. 28 ustawy, zawierający dodatkowo cenę i inne warunki nabycia tej nieruchomości ${ }^{31}$.

Zawiadomienie ma więc, po pierwsze, wywołać reakcję w postaci przystapienia drugiego podmiotu do uzgadniania stanowisk, po drugie, zawiera propozycję jednego ze składników treści umowy, co do którego istnieje wyznaczony ustawowo sposób jego zakomunikowania.

30 Por. P. Machnikowski, (w:) Kodeks cywilny. Komentarz, pod red. E. Gniewka, Warszawa 2006, s. 611.

31 Tak § 4 ust. 2 rozporządzenia Ministra Skarbu z dnia 1 sierpnia 2003 r. w sprawie szczegółowego trybu sprzedaży nieruchomości Zasobu Własności Rolnej Skarbu Państwa i ich części składowych, warunków rozkładania ceny sprzedaży na raty oraz stawek szacunkowych gruntów (Dz.U. Nr 140, poz. 1350), przywoływanego dalej jako „rozporządzenie”. 
Gdyby nie doszło do indywidualnego zawiadomienia uprawnionego, pomimo że aktualizuje się jego pierwszeństwo, ani też w wykazie nie zamieszczono by przynajmniej ceny nieruchomości przeznaczonej do sprzedaży, to trudno byłoby stać na stanowisku, że i tak ma on roszczenie o zawarcie umowy sprzedaży. Cenę nieruchomości, zgodnie z art. 30 ust. 1, co do zasady ustala się w wysokości nie niższej niż wartość tej nieruchomości, określona przy zastosowaniu sposobów jej ustalania przewidzianych w przepisach o gospodarce nieruchomościami. Skoro więc cena może być ustalona na poziomie nie niższym niż jej wartość, oznacza to, że nie musi być jej (tj. wartości nieruchomości) równa, ale może być od niej wyższa ${ }^{32}$. Nie oznacza to, że Agencja Nieruchomości Rolnych ma pełną swobodę w określeniu górnego pułapu ceny, przez co mogłaby faktycznie torpedować pierwszeństwo przysługujące uprawnionym podmiotom. Na tle u.g.n. Sąd Najwyższy w wyroku z dnia 15 stycznia 2003 r. $^{33}$ słusznie uznał, że możliwość oznaczenia ceny na poziomie dowolnie wyższym od wartości nieruchomości czyniłaby przywilej pierwszeństwa iluzoryczny, niweczyłaby możliwość skorzystania z wyznaczonej ustawą preferencji - „umożliwiałaby ominięcie zakazu zadysponowania rzeczą przewidzianego w art. 34 ustawy o gospodarce nieruchomościami”. Wypada więc uznać, że tak jak i na tle u.g.n., tak też przy wyznaczeniu ceny zbywanej nieruchomości dla potrzeb realizacji pierwszeństwa na gruncie u.g.n.r., kompetencja sprzedającego jest zakreślona dwoma wielkościami. Minimalny pułap ceny, poniżej którego nie może on zejść, wyznacza wartość nieruchomości określona przez rzeczoznawcę majątkowego. Górnej wysokości ceny nie można natomiast określić - posługując się sformułowaniami zaczerpniętymi z uzasadnienia wyroku - na poziomie „znacznie wyższym od jej wartości”. Ponieważ sprzedający ma w powyższych granicach swobodę w określeniu ceny nieruchomości, z tego już tylko powodu nie można przyznać roszczenia o zawarcie umowy sprzedaży uprawnionemu z tytułu pierwszeństwa, o ile Agencja sama jej nie wyznaczy - brak bowiem ustawowych kryteriów, które pozwalałyby, z pominięciem woli Agencji, na jej określenie. Z pewnością nie ma żadnych podstaw twierdzenie, że odpowiadałaby wartości nieruchomości ${ }^{34}$. Bez skonkretyzowania ciążącego na kupującym świadczenia polegającego na obowiązku zapłaty ceny nie doszłaby do skutku umowa sprzedaży.

Także i zawiadomienie czy opublikowanie zawierającego cenę i inne warunki nabycia nieruchomości wykazu pełniącego funkcje zawiadomienia nie jest wystarczające dla ewentualnego powstania roszczenia o zawarcie umowy. Taki skutek jest natomiast możliwy do rozważenia, moim zdaniem, w razie wyrażenia zgody na cenę

Por. art. 67 ust. 3 u.g.n, zgodnie z którym przy sprzedaży nieruchomości w drodze bezprzetargowej, o której mowa w art. 37 ust. 2 i 3 , cenę nieruchomości ustala się w wysokości nie niższej niż jej wartość, z zastrzeżeniem ust. $3 a$.

33 IV CKN 1637/00, Lex nr 83823.

34 Por. art. 67 ust. 3a u.g.n., który wyraźnie przewiduje, że jeżeli nieruchomość jest sprzedawana w drodze bezprzetargowej w celu realizacji roszczeń (podkr. R.M.) przysługujących na mocy u.g.n. lub odrębnych przepisów, cenę nieruchomości ustala się w wysokości równej jej wartości. 
i warunki nabycia nieruchomości określone w zawiadomieniu. Mielibyśmy do czynienia z powstaniem stosunku zobowiązaniowego, z którego wynikałby obowiązek zawarcia przez Agencję umowy sprzedaży. Jej postanowienia należy ustalać na podstawie treści zaakceptowanego przez uprawnionego zawiadomienia. Wzgląd na podobieństwo pierwszeństwa regulowanego przez u.g.n., gdzie postanowienia umowy zawieranej z osobą, której przysługuje pierwszeństwo, uważa się za ustalane w rokowaniach, nie musi być uznany za decydujący na gruncie przepisów u.g.n.r. Postanowienia art. 34 ust. 5 u.g.n. stanowiącego, że uprawnieni „korzystają z pierwszeństwa w nabyciu nieruchomości, jeżeli złożą oświadczenie, że wyrażają zgodę na cenę ustaloną w sposób określony w ustawie" oraz art. 29 ust. 1d u.g.n.r., zgodnie z którym osoby uprzywilejowane pierwszeństwem w nabyciu nieruchomości „korzystają z niego, jeżeli złożą oświadczenie, że wyrażają zgodę na jej nabycie po cenie określonej w zawiadomieniu" - ze względu na niemal identyczne sformułowanie mogą zachęcać do ustalenia takich samych konsekwencji złożenia oświadczenia - prowadzenia rokowań ${ }^{35}$. Jak już wzmiankowałem, taka interpretacja nie wydaje się jedyną możliwą. Przepisy u.g.n.r. nie zawierają regulacji wprost przewidujących, że postanowienia umowy sprzedaży mającej być zawartą z uprzywilejowanym pierwszeństwem ustalane są drogą negocjacji (por. art. 28 ust. 2 u.g.n.). W doktrynie należy odnotować wypowiedź, zgodnie z którą zawiadomienie o przysługującym pierwszeństwie oraz zgoda na cenę i warunki nabycia nieruchomości określone w zawiadomieniu nie powinny być uznane za ofertę i jej przyjęcie prowadzące do zawarcia umowy sprzedaży z powodu niezachowania formy aktu notarialnego ${ }^{36}$. Jednak, co istotne dla prowadzonych tu rozważań, przytoczonej opinii milcząco towarzyszy, jak się wydaje, przyjęcie założenia, że pod względem treści powinny być one wystarczającą podstawą ustalenia praw i obowiązków stron przyszłej umowy sprzedaży ${ }^{37}$. Również analiza przepisów regulujących te kwestie potwierdza powyższe wnioski. Przepisy przewidują następujący porządek czynności: zawiadomienie (art. 29 ust. 1c u.g.n.r. oraz $§ .4$ ust. 1 i 2 rozp.), jego akceptacja (art. 29 ust. 1d), wyznaczenie terminu zawarcia umowy sprzedaży ( $\$ 4$ ust. 3 rozp.). W praktyce między Agencją a korzystającym z pierwszeństwa zawierane jest stosowne porozumienie, gdzie zawarte są wszystkie istotne postanowienia przyszłej umowy sprzedaży ${ }^{38}$. Zauważyć trzeba jednak, że nie jest to element procedury wymagany przepisami

O tym, że postanowienia umowy sprzedaży zawierane z osobą, której przysługuje pierwszeństwo nabycia nieruchomości z Zasobu Własności Rolnej Skarbu Państwa ustalane są drogą rokowań tak jak na gruncie u.g.n., opowiedział się ostatnio R. Pessel, Nieruchomości Skarbu Państwa, Warszawa 2008, s. 237. E. Klat-Górska, Pierwszeństwo..., s. 215-216; taż, Przeniesienie własności nieruchomości rolnej - przykłady ograniczeń, Wrocław 2003, s. 85 gdzie autorka dodaje, że chodzi tu tylko o tryb ustalenia treści przyszłej umowy sprzedaży.

37 Por. M. Nazar, Sprzedaż lokali..., s. 138, gdzie autor omawiając pierwszeństwo w u.g.n. odmawia cech oferty zawiadomieniu o przysługującym pierwszeństwie, ponieważ nie zostaje zachowana forma aktu notarialnego. Zaznacza jednocześnie, że czyni to pomijając już kwestię czy zawiadomienie zawiera inne elementy wymagane od oferty.

Por. A. Suchoń, Prawna ochrona trwałości gospodarowania na dzierżawionych gruntach rolnych, Poznań 2006, s. 193. 
prawa; wskazany wprost w przepisach. Nie można wykluczyć, po złożeniu oświadczenia o korzystaniu z pierwszeństwa, dokonania dodatkowych uzgodnień, w tym mających wpływ na treść umowy sprzedaży (np. co do rozłożenia płatności na raty, zabezpieczenia zapłaty należności). Dokonanie ich modyfikowałoby ${ }^{39}$ treść stosunku prawnego (nawiązanego przez akceptację warunków zawarcia umowy określonych w zawiadomieniu) zobowiązującego Agencję do zawarcia umowy ${ }^{40}$.

Ewentualny kontrargument przeciwko prezentowanej koncepcji, zgodnie z którym egzekwowalne roszczenie o zawarcie umowy sprzedaży nie może powstać bez zachowania przy składaniu oświadczeń woli, z których wynika, formy aktu notarialnego (arg. z art. 390 § 2 kc.), nie byłby przekonujący. Jak wynika z wcześniejszych rozważań, skutek taki powstaje w rezultacie pomyślnie zakończonych rokowań dotyczących zbycia nieruchomości stanowiącej własność Skarbu Państwa albo jednostki samorządu terytorialnego na tle u.g.n. Jak wiadomo, jest tak również w przypadku przetargowego trybu zawarcia umowy ${ }^{41}$. Być może pochopne byłoby stawianie na podstawie wskazanych jednostkowych przypadków ogólnej tezy, że w każdym razie, gdy mamy do czynienia z postępowaniem zmierzającym do sprzedaży nieruchomości stanowiącej własność publiczną, na etapie, w którym uzgodniona zostaje treść przyszłej umowy sprzedaży powstaje roszczenie o jej zawarcie. Jednak nie ma tu potrzeby czynienia takiego założenia dla uzasadnienia prezentowanego poglą$\mathrm{du}$ o istnieniu roszczenia o zawarcie umowy przy realizacji pierwszeństwa $\mathrm{z}$ u.g.n.r. Wystarczająco przekonujące, jak sądzę, argumenty wynikają z analizy treści przepisów je ustanawiających. O obowiązku zawarcia umowy przez Agencję świadczy treść przepisów $§ 3$ rozporządzenia, z którego można wnioskować, że przewidziane tam zawiadomienie o miejscu i terminie zawarcia umowy ma służyć wykonaniu obowiązku zawarcia umowy, jak i $\S 4$ ust. 4, z którego a contrario wynika, że poza okolicznościami tam wskazanymi, Agencja nie może uchylić się od zawarcia umowy sprzedaży - a więc spoczywa na niej ów obowiązek ${ }^{42}$.

Roszczenie o zawarcie umowy nie przysługuje Agencji, a jedynie uprawnione$\mathrm{mu}^{43} \mathrm{z}$ tytułu pierwszeństwa. Za takim wnioskiem przemawia sposób, w jaki pra-

Nie jest dopuszczalne jednak prowadzenie negocjacji prowadzących do zmiany ceny określonej w zawiadomieniu, zob. A. Suchoń, Prawna ochrona..., s. 193.

40 Trzeba mieć jednak na uwadze zwłaszcza treść § 22 rozporządzenia Ministra Skarbu Państwa z dnia 1 sierpnia 2003 r. w sprawie nadania statutu Agencji Nieruchomości Rolnych (Dz.U. Nr 140, poz. 1348 z późn. zm.), wymagającego w okolicznościach tam wskazanych szczególnego pełnomocnictwa do zawarcia umowy sprzedaży nieruchomości z ZWRSP. Dokonanie zawiadomienia i jego akceptacja w okolicznościach, w których jest wymagane pełnomocnictwo szczególne przed jego udzieleniem nie może doprowadzić do skutku w postaci powstania roszczenia o zawarcie umowy.

41 Art. $70^{2} \S 3$ kc., art. $70^{3} \S 3$ kc., zob. też znaną uchwałę SN z dnia 2 sierpnia 1994 r., III CZP 96/94, OSNC 1995 nr 1, poz. 11.

42 Por. K. Stefaniuk, Zawarcie umowy w drodze przetargu według ustawy o gospodarce nieruchomościami, Rejent 1999, nr 11, s. 107-108. Autor uzasadniając (Kodeks cywilny nie zawierał wszak wówczas art. $70^{2} \S 3$ i art. $70^{3}$ $\S 3)$ powstanie po stronie wygrywającego przetarg roszczenia o zawarcie umowy sprzedaży stosował taką argumentację, odwołując się do przepisów u.g.n. o podobnej treści.

43 U.g.n.r. używa dla określenia podmiotu, któremu przysługuje pierwszeństwo terminu „uprawniony”; zob. art. 29 ust. 1f, art. 32 ust. 2 pkt 2, jakkolwiek samo użycie powyższych sformułowań nie przesądza charakteru prawnego pierwszeństwa. 
wodawca ukształtował pozycję jego oraz Agencji. To Agencja wyznacza miejsce i termin zawarcia umowy, a jeśli uprawniony bez uzasadnionej przyczyny nie stawi się w wyznaczonym terminie i miejscu w celu zawarcia umowy lub nie spełni warunków określonych w zawiadomieniu, Agencja może przeznaczyć nieruchomość do sprzedaży kolejnej osobie mającej pierwszeństwo w nabyciu tej nieruchomości, a w razie braku takiej osoby - sprzedać ją w przetargu ( $\$ 4$ ust. 4 pkt 3 i 4 rozporządzenia). Z powyższych sformułowań wynika pośrednio, że obowiązek zawarcia umowy ciąży na Agencji, a ustaje w przypadku zajścia okoliczności tam wskazanych. Przepisy rozporządzenia ani u.g.n.r. nie zawierają natomiast żadnych postanowień, które pozwalałyby na wnioskowanie o obustronnym charakterze tego obowiązku, choćby przez wprowadzenie okoliczności uzasadniających odmowę zawarcia umowy przez uprzywilejowanego pierwszeństwem ${ }^{44}$. Dodatkowo można wskazać na okoliczność, że pierwszeństwo jest przecież przywilejem dla oznaczonych osób, krępującym swobodę Agencji w dysponowaniu mieniem Zasobu. Ów przywilej w założeniu umożliwia im nabycie nieruchomości z pominięciem innych zainteresowanych, a więc bez właściwego przetargowi elementu konkurencji uczestników, sprawiającego, że standardowo sposób ustalenia ceny w przetargu jest bardziej korzystny dla organizatora niż przy realizacji pierwszeństwa. Brak jest racji przemawiających za celowością przyznania mu możliwości domagania się zawarcia umowy $\mathrm{z}$ uprzywilejowanym pierwszeństwem, ponieważ $\mathrm{w}$ razie rezygnacji przez niego z zawarcia umowy, Agencja inicjuje w założeniu korzystniejszą dla siebie ekonomicznie procedurę przetargową ${ }^{45}$.

Z charakterem i konstrukcją pierwszeństwa w nabyciu nieruchomości wiąże się bezpośrednio problematyka ustalenia konsekwencji prawnych jego naruszenia. W literaturze i orzecznictwie zarysowały się istotne różnice poglądów w tej kwestii. Według pierwszego z nich, konsekwencją jest nieważność czynności prawnej dokonanej z pominięciem uprzywilejowanego pierwszeństwem, według drugiego - jedynie odpowiedzialność odszkodowawcza, zgodnie zaś z trzecim stanowiskiem - sprzedaż dokonana z pominięciem uprawnionego może zostać uznana za bezskuteczną względem niego (art. 59 kc.). Na tle u.g.n. zdecydowanie dominuje stanowisko, zgodnie z którym konsekwencją naruszenia pierwszeństwa jest powstanie obowiązku naprawienia szkody. Pogląd ten opiera się między innymi na spostrzeżeniu, że art. 36 u.g.n. ustanawiający odpowiedzialność na zasadach ogólnych w razie naruszenia pierwszeństwa, wyłącza dalej idącą sankcję nieważności czynniem z racji braku zainteresowanych nabyciem nieruchomości, a cena wywoławcza w kolejnych przetargach zostaje obniżona. Stąd zawarcie umowy w rezultacie skorzystania z pierwszeństwa mogłoby być w danych okolicznościach mniej korzystne dla uprzywilejowanego pierwszeństwem niż zawarcie umowy w drodze przetargu (por. J. Nadler, Wady regulacji prawnej gospodarowania nieruchomościami rolnymi Skarbu Państwa, (w:) Prawo rolne. Problemy teorii i praktyki, s. 157; E. Klat-Górska, Pierwszeństwo..., s. 216. Jednak modelowo tryb przetargowy realizujący funkcję optymalizacji ceny jest bardziej korzystny dla organizatora. 
ności prawnej ${ }^{46}$. Jednak nie da się mówić o pełnej jednolitości stanowisk, ponieważ wyrażane są również opinie, że naruszenie pierwszeństwa statuowanego przepisami u.g.n. pociąga za sobą nieważność czynności prawnej dokonanej z pominięciem uprzywilejowanego ${ }^{47}$. Jako że byłoby to naruszenie ustawowego zakazu, pociągałoby konsekwencje określone w art. $58 \S 1 \mathrm{kc}$. Art. 36 natomiast nie kreuje nowej podstawy odpowiedzialności, która wynika wprost z przepisów Kodeksu cywilnego. Jest w istocie zbędny, bo nie wprowadza nic nowego w zakresie przepisów Kodeksu cywilnego dotyczących odpowiedzialności odszkodowawczej ${ }^{48}$. Należy odnotować też głosy, aczkolwiek nie poparte szczegółową argumentacją, opowiadające się za skutkiem w postaci powstania odpowiedzialności odszkodowawczej, jak i możliwością uznania czynności prawnej uchybiającą pierwszeństwu za bezskuteczną względem uprzywilejowanemu z tego tytułu (art. 59 kc.) ${ }^{49}$.

$\mathrm{Na}$ tle regulacji pierwszeństwa w nabyciu nieruchomości w u.g.n.r. do niedawna jeszcze zdecydowanie dominował pogląd, zgodnie z którym sankcją za jego naruszenie jest nieważność czynności prawnej (art. $58 \S 1 \mathrm{kc}$.) ${ }^{50}$. Jego zwolennicy odwoływali się przy tym do stanowiska zajmowanego przez Trybunał Konstytucyjny ${ }^{51}$ i Sąd Najwyższy ${ }^{52}$ na gruncie pierwszeństwa wynikającego z u.g.g. (zob. zwłaszcza art. 23 ust. 4 u.g.g.). Nie można przeoczyć, że za nieważną uznał Sąd Najwyższy umowę sprzedaży zawartą z pominięciem pierwszeństwa najemcy lokalu mieszkalnego przewidzianego przez art. 43 u.g.n.r. ${ }^{53}$ Zwolennicy powyższego poglądu argumentowali także, że skoro u.g.n.r. nie zawiera przepisu wyłączającego na wzór art. 36 u.g.n. sankcję określoną w art. 58 § 1 kc., to należy przyjąć, że właśnie ostatni wymieniony przepis wyznacza skutki naruszenia pierwszeństwa. Ostatnio jed-

Tak zwłaszcza E. Gniewek, Obrót nieruchomościami..., s. 200; M. Nazar, Sprzedaż lokali..., s. 146, G. Bieniek, (w:) Ustawa o gospodarce nieruchomościami. Komentarz, pod red. G. Bieńka, Warszawa 2008, s. 233; S. Rudnicki, Prawo odkupu..., s. 540; B. Wierzbowski, Gospodarka nieruchomościami, Warszawa 2008, s. 132. To stanowisko prezentuje Sąd Najwyższy; zob. wyrok z dnia 7 marca 2004 r., IV CKN 1842/00, OSNC 2004, nr 5, poz. 84, wyrok z dnia 25 marca 2004 r., II CK 268/03, Lex nr 347269.

47 Tak W. Nalaskowski, Sankcja za naruszenie przepisów regulujących pierwszeństwo w ustawie o gospodarce nieruchomościami, Przegląd Sądowy 2002, nr 5, s. 46; E. Kremer, Pierwszeństwo w nabyciu nieruchomości w trybie bezprzetargowym - na podstawie ustawy o gospodarowaniu nieruchomościami rolnymi Skarbu Państwa, Rejent 2000, nr 7-8, s. 102-103; R. Padrak, Pierwszeństwo nabycia..., s. 71; tenże, Sprzedaż nieruchomości..., s. 35.

48 E. Kremer, Pierwszeństwo..., s. 102. W. Nalaskowski pisze o edukacyjnym jedynie charakterze przepisu art. 36 u.g.n.; tenże, Sankcja..., s. 147.

49 J. Frelich, Zasada pierwszeństwa..., s. 91; C. Woźniak, (w:) Nieruchomości. Zagadnienia prawne, pod red. H. Kisilowskiej, Warszawa 2007, s. 120.

50 K. Świderski, Charakter prawny pierwszeństwa..., s. 106-107; E. Kremer, Pierwszeństwo..., s. 102-103; taż, Instytucja pierwszeństwa..., s. 143; E. Klat-Górska, Pierwszeństwo..., s. 217; taż, Przeniesienie własności..., s. 85; A. Oleszko, Prawo rolne, Kraków 2004; s. 234, A. Suchoń, Prawna ochrona..., s. 194-196; por. też wyrok Sądu Najwyższego z dnia 28 września 2000 r., IV CKN 108/00, OSNC 2001, nr 3, poz. 40.

$51 \quad$ Uchwała Trybunału Konstytucyjnego z dnia 18 czerwca 1996 r., OTK 1996, nr 3, poz. 25.

52 Sąd Najwyższy konsekwentnie stoi na stanowisku, że jego naruszenie powodowało bezwzględną nieważność czynności prawnej; por. wyrok SN z dnia 29 kwietnia 2005 r, V CK 499/04, Lex nr 311329; wyrok SN z dnia 17 lutego 2005 r., IV CK 596/04, Lex nr 284207; wyrok SN z dnia 26 lipca 2000 r., II CKN 1181/00, Lex nr 51968.

53 Wyrok SN z dnia 28 września 2000 r., przywołany w przyp. 49. Wyrok został wydany na tle art. 42 u.g.n.r. sprzed zmiany dokonanej przez art. 8 ustawy z dnia 15 grudnia 2000 r. o zasadach zbywania mieszkań będących własnością przedsiębiorstw państwowych, niektórych spółek handlowych z udziałem Skarbu Państwa, państwowych osób prawnych oraz niektórych mieszkań będących własnością Skarbu Państwa (Dz.U. z 2001 r. Nr 4, poz. 24). 
nak, pod wpływem przywoływanej wcześniej uchwały Sądu Najwyższego z dnia 21 grudnia 2006 r., coraz więcej zwolenników zyskuje pogląd o odszkodowawczej jedynie sankcji za naruszenie pierwszeństwa z u.g.n.r. Rozstrzygnięcie powyższego dylematu jest istotne również w perspektywie przyjętej przeze mnie koncepcji, zgodnie z którą uprzywilejowany z tytułu pierwszeństwa ma roszczenie o zawarcie umowy sprzedaży. Ma ono znaczenie dla określenia konsekwencji mogących nastąpić przed jego (tj. roszczenia) powstaniem - w przypadku niedopuszczenia do skorzystania z pierwszeństwa (niepoinformowanie o przysługującym pierwszeństwie czy też uniemożliwienie skorzystania z niego, przykładowo, przez złożenie propozycji zawarcia umowy z ceną znacznie przekraczającą jej wartość).

Sąd Najwyższy uznał, że regulacja pierwszeństwa w u.g.n. ma charakter modelowy i stąd sankcja za jego naruszenie określona w art. 36 u.g.n. (przy braku w u. g.n.r. przepisu określającego skutki naruszenia pierwszeństwa) powinna znaleźć zastosowanie również na gruncie przepisów regulujących zbywanie nieruchomości z ZWRSP. Nie może tu wchodzić w grę art. $58 \S 1 \mathrm{kc}$., ponieważ dotyczy jedynie sprzeczności treści czynności prawnej z ustawą. Powszechnie uznaje się również, że art. $58 \S 1 \mathrm{kc}$. określa także skutki uchybienia przewidzianej w ustawie, obligatoryjnej procedurze zawarcia umowy. Ale, zdaniem Sądu, obowiązki określone w przepisach u.g.n.r. dotyczących analizowanej instytucji nałożone na Agencję mają na celu ustalenie, czy uprzywilejowany wyraża zamiar skorzystania z pierwszeństwa, a więc fakt jego aktualizacji. Dla jego powstania nie jest natomiast potrzebne przeprowadzenie sformalizowanej procedury wstępnej. Stąd naruszenie pierwszeństwa nie może być postrzegane jako naruszenie procedury prowadzącej do zawarcia umowy.

W literaturze, jak wspomniałem, w niektórych wypowiedziach wyrażana jest aprobata dla stanowiska zajętego w uchwale z dnia 21 grudnia 2006 r. Według R. Trzaskowskiego, z racji na podobieństwo normowanych sytuacji stosowany per analogiam art. 36 u.g.n. powinien również określać konsekwencje naruszenia pierwszeństwa, gdy ustawodawca nie przewidział skutków zawarcia umowy sprzedaży z pominięciem uprzywilejowanego ${ }^{54}$. Do rozwiązania przyjętego w art. 36 u.g.n. odnosi się jednak krytycznie, stwierdzając, że sankcja tam przewidziana będzie nieraz iluzoryczna z racji trudności w wykazaniu poniesionej szkody. A. Oleszko uznał, że przy pierwszeństwie należy zapewnić potrzebę ochrony prawnej przewidzianej dla różnych sytuacji. W ramach pierwszeństwa uregulowanego w u.g.n.r. nie występuje potrzeba przyjęcia sankcji nieważności czynności prawnej o skutku rozporządzającym $^{55}$. Natomiast J. Ciszewski wyraził przekonanie, że sankcja nieważności nie może być domniemywana, ale wyraźnie przewidziana na wypadek naruszenia nor- 
my prawnej. A brak jest przecież przepisu wprowadzającego sankcję nieważności na wypadek naruszenia pierwszeństwa na gruncie u.g.n.r. ${ }^{56}$

Krytycznie do omawianej uchwały odniosła się natomiast E. Kremer. Stwierdziła, że argumentacja Sądu opiera się na dwóch wykluczających się wzajemnie założeniach: z jednej strony uznał, że art. 36 u.g.n. jest wyrazem wyraźnej woli prawodawcy niewiązania z naruszeniem pierwszeństwa sankcji nieważności czynności prawnej, z drugiej zaś, że przepisy dotyczące pierwszeństwa nie dotyczą treści czynności prawnej, a więc nie mogą być kwalifikowane w kategorii naruszenia art. $58 \S$ $1 \mathrm{kc}$. Przez to rozumowanie zaprezentowane w uzasadnieniu uchwały jest nieprzekonujące i nie może zostać uznane za definitywnie rozstrzygające omawianą kwestię $^{57}$.

Wskazanie, która z zaprezentowanych koncepcji ma mocniejsze podstawy skłaniające do jej zaaprobowania, wymaga przeprowadzenia szczegółowej analizy. Bez wątpienia rację ma E. Kremer wskazując, że tak sformułowane argumenty zaczerpnięte $\mathrm{z}$ uzasadnienia uchwały są oparte na wykluczających się wzajemnie przesłankach. Na zaprezentowaną tam argumentację można jednak spróbować spojrzeć z innej niż autorka perspektywy. Sąd Najwyższy twierdząc, że art. 36 u.g.n. znajdzie zastosowanie $\mathrm{w}$ razie naruszenia pierwszeństwa wynikającego z u.g.n.r., nie mógł pominąć najistotniejszego i najczęściej przywoływanego chyba argumentu przez zwolenników tezy o wyłączności odpowiedzialności odszkodowawczej (zgodnie z którym art. 36 u.g.n. wyłącza dalej idącą sankcję nieważności) - uzasadniając przyjęte przez siebie stanowisko. W uzasadnieniu uchwały stwierdza, że aprobuje orzeczenia Sądu Najwyższego, gdzie upatrywano w art. 36 u.g.n. ,wyraźną wolę ustawodawcy zmierzającą do niewiązania z naruszeniem pierwszeństwa sankcji nieważności czynności prawnej”. Zwraca uwagę to, że w zacytowanym fragmencie nie mówi się o wyłączeniu, ale o niewiązaniu sankcji nieważności z naruszeniem pierwszeństwa. Takie sformułowanie mogłoby sugerować, że Sądowi nie chodziło o wyłączenie sankcji nieważności, która miałaby zastosowanie, gdyby nie odmienna, wyraźna decyzja prawodawcy, lecz o dokonanie wyboru spośród gamy takich sankcji, z których żadna nie posiadałaby prymatu nad pozostałymi (a więc musiałaby zostać wyłączona). Na rzecz stanowiska autorki zdaje się jednak przemawiać fakt, że w tym fragmencie wywodów Sąd odwołuje się do wyroków ${ }^{58}$, których uzasadnienia zawierają wyraźne stwierdzenia o wyłączeniu sankcji nieważności. Stąd zastrzeżenia E. Kremer nie mogą ostatecznie być potraktowane jako pozbawione podstaw.

56 J. Ciszewski, Glosa do uchwały SN z dnia 21 grudnia 2006 r., III CZP 121/06, Gdańskie Studnia Prawnicze Przegląd Orzecznictwa 2008, nr 2, s. 91.

57 E. Kremer, Glosa do uchwały Sądu Najwyższego z 21 grudnia 2006 r., III CZP 121/06, Przegląd Prawa Rolnego 2008, nr 1, s. 321-322.

58 Zob. wyroki Sądu Najwyższego przywołane w przyp. 46. 
Drugi z argumentów zawartych w uchwale z dnia 21 grudnia 2006 r., negujący kwalifikację naruszenia pierwszeństwa w kategorii sprzeczności z art. 58 § $1 \mathrm{kc}$., sformułowała wcześniej B. Burian ${ }^{59}$. Nie był on podnoszony w poprzedzających tę uchwałę rozstrzygnięciach Sądu Najwyższego. To, że nie mamy wówczas do czynienia ze sprzecznością treści czynności prawnej z ustawą, jest spostrzeżeniem mającym poważne podstawy. Zastrzeżenia budzi jednak generalne wyłączenie samej już tylko ewentualności dokonania kwalifikacji uchybienia pierwszeństwu na podstawie art. $58 \S 1 \mathrm{kc}$. Poza odosobnionym głosem B. Burian nie zgłaszano w doktrynie wątpliwości co do jego dopuszczalności. Nie jest oczywiste stwierdzenie, że obowiązki, którym musi zadośćuczynić Agencja, mają na celu jedynie ustalenie, czy uprzywilejowany zamierza korzystać z pierwszeństwa, nie są więc elementami procedury zawarcia umowy. Nie zmienia tego faktu trafna uwaga zawarta w uzasadnieniu uchwały, że dla powstania pierwszeństwa nie jest wymagane przeprowadzenie sformalizowanej procedury wstępnej. Jest to szczególnie widoczne na tle bronionej tu koncepcji, zgodnie z którą akceptacja warunków określonych w zawiadomieniu prowadzi do powstania roszczenia o zawarcie umowy sprzedaży. Nawet jednak odrzucając ją, a podążając za dominującym w doktrynie i orzecznictwie stanowiskiem, to w realizacji pierwszeństwa należałoby dostrzegać „,szczególną technikę prowadzenia rokowan" 60 . Gdyby przyjąć celowość oddzielnego traktowania zawiadomienia o pierwszeństwie od samego procesu uzgadniania treści umowy, to nie sposób nie zauważyć, że następstwem wyrażenia chęci skorzystania z pierwszeństwa powinny być rokowania prowadzące do ustalenia treści umowy sprzedaży. Stąd pominięcie uprzywilejowanego pierwszeństwem poprzez niestworzenie sposobności korzystania z niego mogłoby jednocześnie spowodować niewypełnienie obowiązku przeprowadzenia rokowań z potencjalnym nabywcą. W tym miejscu pojawia się jednak uzasadniona wątpliwość, czy nie mamy więc do czynienia z pominięciem wymaganej ustawowo wymaganej procedury zawarcia umowy.

Nawet gdyby jednak uznać, że naruszenie pierwszeństwa nie jest równoznaczne z naruszeniem obligatoryjnej procedury zawarcia umowy, to nie należy z góry wykluczać zastosowania art. 58 § $1 \mathrm{kc}$. w drodze analogii, jeśli cel, któremu pierwszeństwo ma służyć dostatecznie uzasadnia jego przyjęcie ${ }^{61}$.

Powyższe uwagi nie zmieniają jednak faktu, że teza o modelowym charakterze art. 36 u.g.n. jest jak najbardziej możliwa do obrony, znajduje zresztą coraz więcej zwolenników. Wypada zgodzić się z J. Ciszewskim, że nie ma tu, tak jak i w innych

59 B. Burian, Pierwszeństwo..., s. 216-217.

60 K. Świderski, Charakter prawny pierwszeństwa..., s. 103. Spostrzeżenie autora, sformułowane na tle art. 34 u.g.n. można odnieść do pierwszeństwa z u.g.n.r. Opinię, że naruszenie pierwszeństwa to uchybienie bezwzględnie obowiązującym normom prawnym regulujących tryb zawarcia umowy wyraża E. Gniewek, O skutkach naruszenia zasad pierwszeństwa nabycia nieruchomości skarbowych i samorządowych - krótka polemika, Przegląd Sądowy 2002, nr 10, s. 107. 61 Por. R. Trzaskowski, Skutki naruszenia..., s. 263-264. SN w omawianej uchwale wykluczył zastosowanie art. 58
§ 1 kc. z powołaniem się na cel regulacji. 
przypadkach naruszenia normy bezwzględnie wiążącej, podstaw do automatycznego stosowania konsekwencji z art. $58 \S 1 \mathrm{kc}$. Jej określenie powinno zaś być poprzedzone analizą całokształtu regulacji pierwszeństwa w u.g.n.r. Należy przy tym ustalić zarówno wartości jakie uzasadniały przyznanie przez prawodawcę określonym kategoriom podmiotów pierwszeństwa, która sankcja jest adekwatna ze względu na wagę tychże wartości, uwzględniając przy tym, jakie praktyczne następstwa zastosowanie danej sankcji pociągnie za sobą w obrocie.

Trybunał Konstytucyjny w uchwale z dnia 18 czerwca 1996 r. uznał, że pierwszeństwo z art. 23 ust. 4 u.g.g. przysługujące byłym właścicielom jest wyrazem tendencji reprywatyzacyjnych i służy poszanowaniu ich słusznych interesów. Stąd waga urzeczywistnianych poprzez tę regulację wartości uzasadnia uznanie czynności prawnej naruszającej pierwszeństwo za nieważną (art. $58 § 1 \mathrm{kc}$.). W zakresie wyznaczonym przez art. 29 ust. 1 pkt 1 u.g.n.r. również można powołać się na powyższe uzasadnienie aksjologiczne, jednak w przypadku osób wskazanych w pkt 2 4 ust. 1 art. 29 u.g.n.r. należy odwołać się do innych racji. Podstawowe pytanie, jakie należy tu sobie zadać - to czy owe racje są na tyle doniosłe aby przyjąć, że ich ochrona wymaga zastosowania sankcji nieważności. Uważam przy tym, że niedopuszczalne byłoby przyjęcie, że naruszenie pierwszeństwa tylko niektórych kategorii uprzywilejowanych pociąga za sobą następstwa określone w art. 58 § $1 \mathrm{kc}$., zaś nierespektowanie przywileju pozostałych powoduje powstanie odpowiedzialności odszkodowawczej, a to ze względu na systemową spójność regulacji prawnej. Dużo wątpliwości pojawia się jednak przede wszystkim w przypadku określonym w art. 29 ust. 1 pkt 3, zgodnie z którym pierwszeństwo mają dzierżawcy gruntów Zasobu, jeśli umowa dzierżawy trwała faktycznie co najmniej 3 lata. W odniesieniu do gruntów rolnych ustawodawstwo chroni od dawna pozycję dzierżawców poprzez ustawowe prawo pierwokupu, którego naruszenie powoduje nieważność czynności prawnej (zob. uchylony art. $695 \S 2$ kc., art. $599 \S 2$ kc., art. 9 ust. 1 ustawy z dnia 11 kwietnia 2003 r. o kształtowaniu ustroju rolnego ${ }^{62}$ ). Jednak, co trzeba wyraźnie zaakcentować, pierwokup na podstawie u.k.u.r. przysługuje jedynie dzierżawcy będącemu rolnikiem indywidualnym prowadzącym gospodarstwo rodzinne, spełniającemu ściśle określone kryteria ustawowe. Brak jest takich szczególnych wymogów przy pierwszeństwie dzierżawców na podstawie u.g.n.r., co prowadzić może do wniosku, że nie znajduje dostatecznego uzasadnienia aksjologicznego przyjęcie sankcji nieważności dla jego naruszenia, skoro ustawodawca przewiduje ją wyraźnie dopiero przy naruszeniu uprawnienia przyznanego po spełnieniu bardziej rygorystycznych warunków. Uznając, że nie ma wystarczających podstaw dla przyjęcia sankcji nieważności dla pierwszeństwa dzierżawców, można zrezygnować z analizy podstaw aksjologicznych pierwszeństwa zarządzającego specjalną strefą ekonomiczną. Uzasadnienia dla tej decyzji należy poszukiwać w treści art. 29 ust. 1f, 
zgodnie z którym w razie zbiegu uprawnień z tytułu pierwszeństwa stosuje się kolejność określoną w ust. 1 niniejszego artykułu. Zatem skoro pierwszeństwo dzierżawców stoi wyżej w hierarchii niż pierwszeństwo podmiotu zarządzającego, to konsekwencje naruszenia tego ostatniego nie powinny być bardziej dotkliwe niż je wyprzedzającego, skoro w oczach prawodawcy posiada niższy priorytet ${ }^{63}$.

Powyższe rozważania dowodzą, że trudno jest mówić o jednolitości, równie doniosłej wadze, czy też równorzędności celów, którym ma służyć pierwszeństwo w odniesieniu do poszczególnych kategorii uprzywilejowanych skłaniających do przyjęcia jednolitej sankcji nieważności na wypadek jego naruszenia dla wszystkich grup uprzywilejowanych. Wątpliwości wzbudza natomiast możliwość uznania, że naruszenie pierwszeństwa w ramach jednej regulacji rodzi zróżnicowane konsekwencje w zależności od grupy uprzywilejowanych, do której ją odnosimy.

Sprzeciw budzi zgłoszona w doktrynie propozycja, aby nieważność czynności prawnej naruszającej pierwszeństwo rozpatrywać poprzez art. $58 \S 2$ kc., a więc jako sprzeczną z zasadami współżycia społecznego, ze względu na jego moralny aspekt pierwszeństwa podkreślany przez Trybunał Konstytucyjny ${ }^{64}$. Oczywiście nie można wykluczyć, że w danych okolicznościach rozporządzenie nieruchomością naruszy zasady współżycia społecznego, ale generalna kwalifikacja naruszenia pierwszeństwa przez pryzmat art. $58 \S 2 \mathrm{kc}$., abstrahująca od okoliczności konkretnego przypadku jest wadliwa ${ }^{65}$. Generalnie można rozpatrywać naruszenie pierwszeństwa jedynie jako naruszające przepisy prawa. Stawianie w ich miejscu - jako wyznacznika ważności - umowy sprzedaży - zasad współżycia społecznego, nie relatywizowanych do okoliczności konkretnej sprawy, byłoby równoznaczne z nieuprawnionym zastępowaniem woli ustawodawcy.

Jest charakterystyczne, że zwolennicy poglądu o nieważności czynności prawnej dokonanej z naruszeniem pierwszeństwa podkreślają, że zasada pierwszeństwa ma znaczenie nie mniejsze niż zasada przetargu, czego praktyczną konsekwencją jest niestosowanie przy wykładni przepisów dotyczących pierwszeństwa reguły exceptiones non sunt extendendae ${ }^{66}$. Z kolei autorzy opowiadający się za odszkodowawczymi jedynie konsekwencjami naruszenia pierwszeństwa traktują je jako odstępstwo od zasady przetargu i nie dopuszczają rozszerzającej wykładni przepisów

Wartości, jakie ma urzeczywistniać realizacja pierwszeństwa przysługującego podmiotom zarządzającym specjalnymi strefami ekonomicznymi należy rekonstruować z treści art. 3 ustawy z dnia 20 października 1994 r. o specjalnych strefach ekonomicznych (Dz.U. z 2007 r. Nr 42, poz. 274, z późn. zm.) określającego, jakim celom ma służyć ich funkcjonowanie.

64 Zob. R. Padrak, Sprzedaż nieruchomości..., s. 35; tenże, Pierwszeństwo nabycia..., s. 71. $65 \begin{aligned} & \text { Por. wyrok Sądu Najwyższego z dnia } 9 \text { lipca } 1999 \text { r., III CKN 98/99, OSP 2000, nr 1, poz. } 5 \text { (dotyczył naruszenia } \\ & \text { pierwszeństwa uregulowanego w ustawie z } 13 \text { października } 1994 \text { r. Prawo łowieckie - Dz.U. Nr 1447, poz. 713). }\end{aligned}$ S. Rudnicki trafnie zwrócił uwagę w glosie do tego wyroku, że naruszenie zasad współżycia społecznego może być rozpatrywane jedynie gdy bierze się pod uwagę okoliczności dokonania danej czynności prawnej (tamże, s. 15). 
dotyczących omawianej instytucji ${ }^{67}$. Tu może rodzić się pokusa innego jeszcze uzasadnienia dla sankcji nieważności w razie uchybienia pierwszeństwu. Mianowicie, jeśliby przyjąć założenie, że zasada pierwszeństwa jest równorzędna zasadzie przetargu, to stąd już tylko krok do konkluzji, że konsekwencje naruszenia obu zasad powinny być tożsame ze względu na ich równą wagę. A skoro jest bezsporne, że naruszenie przetargowego trybu zawarcia umowy powoduje następstwa $\mathrm{z}$ art. $58 \S 1 \mathrm{kc}$., to także w razie naruszenia pierwszeństwa winien on znaleźć zastosowanie. Taki tok rozumowania obarczony jest jednak zasadniczym błędem. Otóż teza o równorzędności obu powyższych zasad nie ma apriorycznego charakteru, ale wynika $\mathrm{z}$ argumentacji opierającej się na wartościach, których urzeczywistnieniu one służą (tj. zasady przetargu i pierwszeństwa). Inaczej rzecz ujmując, teza o równorzędności nie jest aksjomatycznym założeniem, z których wyciąga się kolejne wnioski, ale są rezultatem pewnej argumentacji. Tak więc nie można, uzasadniając tezę o nieważności czynności prawnej dokonanej z pominięciem pierwszeństwa, odwoływać się do równorzędności pierwszeństwa i zasady przetargu bez uprzedniego wykazania na podstawie argumentacji odwołującej się do wartości, które ma urzeczywistniać realizacja pierwszeństwa, iż uzasadniają one taką rangę owego przywileju. Na podstawie wcześniejszych wywodów widać, że jest to mocno problematyczne.

Przeciwko analogicznemu stosowaniu art. 36 u.g.n. do pierwszeństwa nabycia nieruchomości ZWRSP mogłaby przemawiać ujemna ocena tego przepisu ${ }^{68}$. W doktrynie takie oceny zostały wyrażone ${ }^{69}$. Jednak obok głosów krytyki odnotować trzeba również opinie, że regulacja art. 36 u.g.n. jest bardziej adekwatna niż sankcja nieważności ${ }^{70}$. Można wskazać także stanowisko głoszące, że wprawdzie sankcja wskazana w art. 36 u.g.n. nie zabezpiecza w pełni interesu uprzywilejowanego pierwszeństwem, to jednak przemawia za nią wzgląd na bezpieczeństwo obrotu. Ryzyko zawierania nieważnych umów sprzedaży, przy przyjęciu sankcji nieważności czynności naruszającej pierwszeństwo, naruszałoby interes publiczny, jako że pociągałoby za sobą uzyskiwanie niższych cen przy sprzedaży nieruchomości publicznych ${ }^{71}$. Różnice poglądów wyrażanych w piśmiennictwie są rzeczą normalną, a nie ma podstaw do utrzymywania, że art. 36 jest jednoznacznie negatywnie oceniany przez doktrynę, co stanowiłoby istotny argument przeciwko jego analogicznemu stosowaniu w sytuacjach wyraźnie nim nieobjętych.

Odnotować można jeszcze jeden głos polemiczny w stosunku do argumentów zawartych w uchwale Sądu Najwyższego z dnia 21 grudnia 2006 r. Autor, referując stanowisko zajęte przez Sąd Najwyższy w powyższej uchwale jednak podaje,

67 G. Bieniek, Prawo pierwokupu, odkupu i pierwszeństwo nabycia, (w:) G. Bieniek, Rudnicki, Nieruchomości. Problematyka prawna, Warszawa 2007, s. 539.

68 R. Trzaskowski, Skutki naruszenia..., s. 261.

69 Jednoznacznie negatywnie ocenia art. 36 u.g.n. E. Gniewek, Obrót nieruchomościami..., s. 200.

70 B. Wierzbowski, Gospodarka nieruchomościami, przypis 18 na stronie 132.

71 R. Trzaskowski, Skutki naruszenia..., s. 264. 
że wynika z niego, iż przywilej pierwszeństwa nie jest czynnością prawną. Takie ujęcie sprawy przez autora samo w sobie jest niepoprawne; podstaw dla jego sformułowania próżno zresztą szukać w uzasadnieniu uchwały. Teoretycznie, jeśli już odnosić do czegoś pojęcie czynności prawnej, to do sposobu korzystania z pierwszeństwa. Czym innym jest ów przywilej, czym innym sposób korzystania z niego. Zdaniem autora, możliwe jest - idąc za wnioskami Sądu Najwyższego wyrażonego w innym miejscu ${ }^{72}$ - traktowanie zawiadomienia o przysługującym pierwszeństwie jako specyficznej formy oferty. To stwierdzenie ma być podstawą dla wniosku, że ,„podejmowane czynności prawne na etapie wstępnym, jak zawiadomienie oraz złożenie oświadczenia (...) o akceptacji ceny podanej w zawiadomieniu, stanowią jednak elementy czynności prawnej. Powinny być zatem uznane jako składniki czynności prawnej, które w przypadku ich sprzeczności z ustawą skutkują ich nieważnością"73. Brak tu wyjaśnienia, składnikami jakiej czynności prawnej, skierowanej na wywołanie jakich skutków prawnych są zawiadomienie i jego akceptacja. Z pewnością nie można przyjąć, że umowy sprzedaży. Być może jakiejś czynności poprzedzającej zawarcie umowy sprzedaży, traktowanej przy tym jako przesłanka ważności tej ostatniej, jednak brak u autora rozważań uzasadniających powyższe przypuszczenie. Jest to tym bardziej niejasne, że opowiada się on za koncepcją, w myśl której pierwszeństwo realizowane jest poprzez negocjacje ${ }^{74}$. W odniesieniu do rozważań zawartych w komentowanej uchwale z dnia 21 grudnia 2006 r., argument, że czynność prawna, w razie sprzeczności z ustawą, jest nieważna, nie może zostać uznany za satysfakcjonujący, ponieważ w żaden sposób nie odnosi się do powołanych w uzasadnieniu uchwały przesłanek mających skłaniać do przyjęcia innego skutku naruszenia pierwszeństwa. Samo założenie, że podejmowane działania są czynnościami prawnymi w tym kontekście niczego nie uzasadnia. Wskazane wątpliwości nie pozwalają na uznanie, że w zaprezentowanej wypowiedzi zawarto przekonujące argumenty wystarczające do odrzucenia wniosków wypływających z uchwały z dnia 21 grudnia 2006 r.

Najbardziej więc, moim zdaniem, uzasadnione są argumenty skłaniające do odrzucenia sankcji nieważności czynności prawnej dokonanej z naruszeniem pierwszeństwa osób wymienionych w art. 29 ust.1 u.g.n.r., a przemawiające za wiązaniem $\mathrm{z}$ takim postępowaniem jedynie konsekwencji ograniczających się do naprawienia szkody. Przyjmując, że poprzez wyrażenie zgody na cenę i inne warunki nabycia nieruchomości określone w zawiadomieniu, po stronie uprzywilejowanego pierwszeństwem powstaje roszczenie o zawarcie umowy sprzedaży, umowa sprzedaży nieruchomości zawarta z inną osobą, po wyrażeniu zgody przez uprzywilejowanego, przy spełnieniu przesłanek z art. 59 kc., mogłaby zostać uznana za bezskuteczną 
względem niego ${ }^{75}$. Gdyby zaś Agencja nie stworzyła danej osobie możliwości skorzystania z pierwszeństwa, nie dopuszczając tym samym do powstania roszczenia o zawarcie umowy, skutki takiego postępowania należałoby oceniać poprzez art. 36 u.g.n. stosowany per analogiam.

75 Por. A. Stelmachowski, (w:) System..., s. 370; S. Prutis, (w:) Prawo rolne..., s. 230. Autorzy przyjmuja jednak, jak się wydaje, wcześniejszy moment powstania roszczenia o zawarcie umowy sprzedaży po stronie osób, którym przysługuje pierwszeństwo. 


\section{Legal nature and consequences of violation of priority in acquisition of property belonging to Agricultural Resources of the State Treasury}

\section{Summary}

Nature and consequences of violation of priority in acquisition of property have not been clearly defined by legislator and cause many problems in application. There is a discrepancy in opinions of legal doctrine and in the jurisdiction regarding the said issue. Author stated that the person who accepted the selling price and other conditions set out in notification sent by Agricultural Property Agency, has a right to submit a claim to the court for compulsory conclusion of the property sale agreement. In case of violation of priority, Agricultural Property Agency is liable for causing damage. However, there are no justified reasons to agree that violation of priority causes invalidation of the property sale agreement. 